Review

\title{
Sustainable Development from a Zootechnical Perspective in Peru
}

\author{
${ }^{1}$ José Américo Saucedo-Uriarte, ${ }^{1}$ Hurley Abel Quispe-Ccasa, \\ ${ }^{2}$ Ilse Silvia Cayo-Colca and ${ }^{3}$ Manuel Emilio Milla Pino \\ ${ }^{1}$ Doctoral Program in Sciences for Sustainable Development, National University Toribio Rodríguez of Mendoza, \\ Chachapoyas, Amazonas, Peru \\ ${ }^{2}$ Faculty of Zoo Technical Engineering, Agribusiness and Biotechnology, \\ National University Toribio Rodríguez of Mendoza, Chachapoyas, Amazonas, Peru \\ ${ }^{3}$ Faculty of Civil Engineering, National University of Jaén, Cajamarca, Peru
}

\section{Article history}

Received: 06-08-2021

Revised: 06-10-2021

Accepted: 14-10-2021

Corresponding Author:

José Américo Saucedo Uriarte,

Escuela de Posgrado/National

University Toribio Rodríguez of

Mendoza, Chachapoyas,

Amazonas, Peru

Email: saucedouriarte@gmail.com

\begin{abstract}
Sustainable Development term was born in 1987 and referred to the satisfaction of human needs while preserving the planet resources. There are different interpretations of this definition, but generally, all agree that a Sustainable Development model must be economically viable, socially acceptable and environmentally benign. This manuscript proposes strategies from a zoo technical approach and their contribution to the path for Sustainable Development in Peru. In Peru, a sustainable zoo technical vision will be made up of a conscious and responsible society, promoting a rational small-scale production, understanding the existing relationships between animals, plants, soil, air and water, for a comprehensive and peaceful human nature intervention. For this, the livestock activity will have to review and readjust its foundations for good professional and scientific exercise. It is necessary to avoid the deterioration of virgin regions to install new productive systems instead of implementing techniques that imitate the patterns and relationships in nature, such as permaculture. Finally, a Sustainable Development model should not focus only on accumulating financial benefits because this will quickly lead us to social and environmental poverty.
\end{abstract}

Keywords: Sustainable Development, Sustainable Development Objectives, Economic Model, Animal Production, Food Sovereignty, Endogenous Development

\section{Introduction}

In recent years, the global food crisis worsened due to many factors, including the increase in food prices and the appearance of new diseases such as COVID-19, which contributed to the advance of poverty and extreme poverty (González and Jiménez, 2012; Vaughan, 2020). This phenomenon is due to population growth, extensive rural poverty, the degradation of natural resources (intensive agricultural production, mineral extraction, among others) and climate change. In addition, the increase in food insecurity is due to different changes in environments and lifestyles, as well as social inequality caused by austerity policies (Gracia-Arnaiz, 2021). This situation proposes concentrating efforts to incorporate elements that promote social, economic and environmental sustainability to improve society and its environment.
The term "development" refers to an immanent process of self-movement from the lower (simple) to the higher (complex or developed), subordinate to the general laws of dialectics (which does not accept definitive knowledge). Every singular development process has a beginning and an end, where already at the beginning and its tendency its end is found and that end establishes a new beginning, in a spiral form (Rosental and Iudin, 1965). The phases of development include preparing the premises of its formation, emergence, formation or transformation of the process, proper development or maturity of the process and extinction (Frolov, 1984). Along the same lines, we highlight the question What is sustainable development? According to Novo Villaverde and Zaragoza (2009), it becomes an integrated approach to a new model-oriented by respecting nature and social 
equity, articulating multiple developments approaches on scientific, socio-economic, environmental and educational issues. The concept of sustainable development integrates economic, social, cultural, political and ecological factors (Kates et al., 2001; Gallopín et al., 2000). According to the Brundtland report (1987), sustainable development is the set of activities carried out by man to satisfy his current needs without compromising the resources and possibilities of future generations, guaranteeing the balance between the protection of the environment, social welfare and economic bonanza.

Depending on the economic status of each country, the search for sustainable development varies. For example, the strategies used by developed countries with the use of advanced technologies seek to increase their productivity and reduce their impact on the environment; on the other hand, although, indeed, developing countries do not have advanced technology, the objective is common; mitigate the impact on the environment, grow economically and reduce the social gap.

In Peru, in terms of policies and government, sustainable development is a matter of recent concern. The leading national problem focuses on economic growth, for this reason, the policies are mainly directed to this sector, relegating environmental problems and deepening the social gap. Some antecedents maintain that the Peruvian economy is on the path of sustainable development, but that does not guarantee that the productive base continues to grow endogenously, therefore, the capacity to face future development (Orihuela and Rojas, 2017). Although Gross Domestic Product (GDP) is taken as the classic indicator of economic growth in Peru, for Orihuela and Rojas (2017), this would not necessarily be the most appropriate to evaluate the economy's performance. Peru is a country rich in non-renewable natural resources; therefore, extracting such resources (for example, metals) will eventually increase its economic dynamics and GDP, but at the same time, it will reduce its reserves as natural capital, being able to reduce its ability to generate income in the future. Therefore, if economic growth in Peru is to be improved, within the framework of sustainable development, strategies must be implemented that seek to increase the availability of capital, such as artificial capital, the articulating capital of the economy and institutional capital, the which allocates or redistributes public resources in society.

Regarding the search for social welfare, it is necessary to get the population to join and make development processes their own. However, today the Peruvian government generally limits its policies to material issues (construction of schools, hospitals, roads, among other infrastructures), when there is also the need to generate intrinsic capacities in people, such as education, health and social integration strategies (Solano, 2007). We must emphasize that investment in infrastructure is very relevant, but the generation of capacities in citizens is a priority and fundamental pillar on the path of sustainable development. Along the same lines, it is possible to achieve an environmental balance when there is quality and good use of renewable and non-renewable resources within a territory, respecting natural cycles. Solano (2007) mentions that a society cannot be called "developed" when it has lost its natural capital or is in the process of erosion to generate temporary economic prosperity. In Peru, the classic examples are the extreme exploitation of island guano and indiscriminate fishing, causing the depletion and loss of these resources.

To achieve sustainable development, the balance between these three factors (social, economic and environmental) must be promoted and that their beneficial results can prevail over time. It is not enough to state that, for example, Peru has a GDP growth rate of $8 \%$ per year, knowing that there is still approximately $48 \%$ of poverty as a result of the policies of overexploitation of natural resources and the absence of commitments to the preservation of the environment. According to Vásquez (2007), in response to this globalizing model, endogenous development is proposed as an alternative for selfmanagement and strengthening the local capacities of each territory and crystallizes the vision of the path towards sustainable development. We consider that sustainable development does not become a static goal to be achieved but rather a dynamic process of human activities focused on mitigating and adapting to environmental changes and promoting social and economic well-being.

In 2015, the United Nations Development Program approved the so-called "2030 Agenda", which sets out 17 Sustainable Development Goals (SDG) in order to end poverty, the deterioration of the planet and promote peace in the term until the year 2030. The zoo technical activity has an important role in the fulfillment of many SDGs, directly in the SDG "Zero Hunger" where it has the function of producing safe and affordable food, improving human food and nutrition with quality products, as well as promoting safety and food sovereignty through sustainable agriculture. The professional zoo technician is also the protagonist of the SDG "Responsible production and consumption", guaranteeing sustainable production where good practices are prioritized in their production systems, taking into account natural energy flows and reducing the use of toxic substances. Good practices in animal production indirectly contribute to the SDGs "Action for the climate" and "Life of terrestrial ecosystems", where the efficient use of natural resources can contribute to reduce the emission of greenhouse gases and protect soils and waters of pollution. Animal production can be a useful tool for achieving "Sustainable cities and communities", "Reduced inequalities", "Decent work and economic growth" and even " without poverty". 
In 2017, in Peru an evaluation of the Sustainable Development Index was carried out and it obtained 3.9, considered within a critical level (Dejo and Ventura, 2017), which shows the need to focus on new strategies to achieve the SDGs. Under this purpose, various disciplines such as Animal Production or Zoo technics have an essential role as protagonists of human activities, providing food of animal origin for human consumption. This writing aims to propose strategies from a zoo technical approach to direct sustainable development in Peru.

\section{In the Social Aspect}

Society worldwide is immersed in a system whose general premise is the accumulation of goods and in the course of life, human beings are directly or indirectly educated towards consumption and consumerism (excessive non-essential consumption). This way of living has generated significant needs and greater use of resources (renewable and non-renewable) to cover such needs. At the same time, the gap between the population's social status has increased, in which, on the one hand, a small percentage of the population accumulates assets and has greater purchasing power, while on the other, there is greater poverty and extreme poverty.

This social problem generally occurs in "developing" countries, where the majority of the population in rural areas and some urban areas still cannot meet the minimum levels of their essential needs such as water supply, decent housing, sanitation and sewerage, nutritional status, among others (Romero et al., 1994). Even Zalapa (2012) in this regard cites some international regulations such as those of Economic, Social and Cultural Rights and the Universal Declaration of Human Rights, emphasizing the fundamental right of every human being to be free from hunger and malnutrition. However, the current context shows that the strategies developed and immersed in a capitalist system have not been the most appropriate for their solution. On the contrary, the gap between rich and poor has widened. Without the intention of giving a demagogic impression, we consider that education has the critical function of being an instrument of socialization and critical attitude, in charge of proposing valid alternatives for the challenges of changing human society. Education has constant challenges in its role as educators of children as future citizens, young managers, planners and decisionmakers to guide their values towards a harmonious relationship with their environment (Novo Villaverde, 2009).

Agricultural activity is vital for rural populations, even though it has historically been attributed to the progressive generation of heterogeneity, marginalization and poverty, population expulsion (desegrarization), feminization and ageing (Zalapa, 2012). Worldwide, extensive-scale livestock farming is generally concentrated in rural areas and is carried out by most of the population living in poverty. However, family farming has been displaced towards industrial agriculture, for intensive food production, becoming a way of enrichment and distorting the fundamental value of food in a market scenario, where prices are increasingly high (González and Jiménez, 2012).

Zoo technics plays a fundamental role for society because it is responsible for producing safe and healthy animal origin food, which provides food security for the population. From zoo technics, it is imperative to promote a rational form of production without altering natural cycles and understanding the relationship between animals, plants, soil, air, water for the peaceful intervention of man. In addition, to transform and commercialize these products adopting ethical and equitable criteria. The imbalance between land tenure and the energy flow for the production of feed and food of animal origin generates, on the one hand, concentration and hoarding and on the other, erosion of resources and poverty. Likewise, centralism, difficulties accessing technology in rural areas, lack of communication routes, limited capital and access to financing contribute to this segregation (González and Jiménez, 2012).

Regarding the intensification of animal production, new genetic improvement techniques, advanced nutrition strategies, among others, have made it possible to increase productivity; some sectors indeed disapprove them since they are not sustainable, they promote loss of natural resources (soil, water, biodiversity) and do not contribute to food sovereignty. Delgado-Callisaya et al. (2014) argue that it is possible to adopt better production and transformation techniques, improve the workforce's qualification, integrate processes and seek consumer welfare to exceed their expectations. Thus, animal husbandry contributes to social well-being within the sustainable development framework, integrates smallscale family farming into the food supply at local, regional and national scales, reduces dependence on external inputs for local production through scientifically corroborated strategies. Each pillar of zoo technics produces quality, safe and accessible food, considering the population's health, well-being and food security, balancing the social benefits with the economic ones.

The promotion of small local production seems to be an alternative to threatening situations where the food supply is interrupted. In this scheme, the need for external inputs could be reduced, costs and prices could be reduced and the balance with the environment could be improved (González and Jiménez, 2012). It is here where animal husbandry professionals and related disciplines challenge seeking a change towards new sustainable production strategies. Research and production could focus, for example, on the promotion of animal-plant-soil interaction systems such as silvo pastures, on the use of native biodiversity to improve yields and resistance to diseases, on the use of forages and local inputs for food, in comprehensive strategies for the management of 
diseases and pests in crops and livestock. However, this goal of improving production systems will require commitment and time and the implementation of government agrarian policies based on promoting integral sustainable development favoring the poorest rural agricultural sector. For example, the dairy production chain should be protected from imported products with the privilege of subsidies thanks to trade agreements. Another case is alpaca fiber, which to industrializers would benefit producers (Fairfield, 2006). At the same time, these actions should be considered from the most basic education to the work of research institutions and the government, seeking to improve the living conditions of the rural world and society in general, free from subsidies, extreme poverty and inequity (Arias, 2013).

\section{In the Economic Aspect}

To talk about the economic dimension, we contextualize ourselves in the current model of world economic development, which is based on the exploitation of renewable and non-renewable natural resources imposed by developed countries on developing countries (Romero et al., 1994). Like any production chain, the manufacturing sectors in industrialized countries require raw materials (from developing countries). Then, thanks to a free market system, they distribute their products to the countries from which they obtained such raw materials. As a consequence of this model, the social gap of the rural population in developing countries is intensifying and in developed countries, they improve in economic terms. The same happens in Peru, where economic growth is due to free-market policies to a greater extent. Free market policies allow the entry of foreign capital investment, but on the other hand, they generate the excessive extraction of natural resources, mainly non-renewable resources such as raw materials.

For this reason, it seems that there is an economic boom, but it is not reflected in the reality of the majority of the population, which is why it is perceived as a development model lacking in sustainability destined for collapse. In the World Bank report "Gaining momentum in Peruvian agriculture", it is argued that Peruvian agriculture should be the object of concern for governments and legislators since the economy depends mainly on this sector. If it decreases, general growth will also be affected, generating greater poverty (WBG, 2017).

According to the FAOSTAT portal (http://www.fao.org/faostat/es/\#data/QL), the world population of species of zoo technical interest had a significant increase from 1994 to 2019, which would indicate an increase in GDP of countries. However, this also indicates that more inputs are required to maintain this growing cattle population. In addition to this, intensive livestock farming is established in some geographical regions, promoting an imbalance in the natural recirculation of nutrients due to linear energy flows in feed. Zalapa (2012) argues that livestock is a necessary human activity and is a generator of economic income, but it can be projected towards sustainable development through production intensification; this means a more productive, profitable and less polluting animal; with the use of genetic technology, good nutrition, innovative livestock management systems, among others. However, once again, we are plunged into a spiral where purchasing power and productive capacity is reduced to a few in the livestock industry, while small family farmers increasingly need more external inputs to try to make their productive systems profitable.

Zoo technics is closely linked to the economic growth of this sector of the rural population since the use of products and by-products of domestic animals (milk, meat, eggs, skins, wool, honey, feathers, manure, balanced food animals, show animals, among others), are the product of an investment to which a monetary value or economic conditioner is assigned (Gärtner, 2011; Delgado-Callisaya et al., 2014). Under this close humananimal relationship in zootechnics, the sustainability of a farm must be based on a harmonious coexistence favoring animal welfare, establishing the objective of obtaining optimal yields in this activity (Buxade, 2000). According to Sepúlveda (2003), knowing that the agricultural sector, for the year 2017, was one of the most promising in terms of its contribution to GDP, this activity could show part of the economic stability of a country. Therefore, to achieve sustainable development, it is necessary to carry out a zoo technical activity with integrated approaches that allow, for example, to produce food for the population and feed for animals at a lower cost, safeguard animal welfare in productive systems in search of sustainable productivity and good perception of the population, prevent diseases and reduce the production costs of food of animal origin. Zoo technics and therefore animal production, can contribute to sustainable development since it generates economic returns through good management of resources.

\section{In the Environmental Aspect}

Most of the environmental deterioration could be the responsibility of the prioritization of extractive activity and economic growth in a system of capital accumulation in which the governments of the day are framed. In a purely economic scenario, nature is assigned a strictly commercial function to be used. However, in a sustainable development model, it is necessary to verify that the renewal rate of natural resources is greater than or equal to the same use rate (Romero et al., 1994).

The environmental problem generated by livestock activity is detailed in the report called "The Long Shadow of Livestock" (Steinfeld et al., 2009), which narrates the 
impact of livestock on the environment, divided into four aspects: (1) Air pollution with gases and climate, (2) Land degradation (3) Contamination of water bodies and (4) Loss of biodiversity (Zalapa, 2012). Romero et al. (1994) state that it must be covered from a local-regional point of view (considering land use, human settlements, water, nonenergy mining, forest, marine ecosystems and biological heritage). In the same way, from a global point of view (depletion of the ozone layer, marine pollution, extinction of species, loss of biodiversity, the emergence of new diseases and nuclear risk), since in many ways, the dangers are not limited to national borders but threaten the whole world.

In the role of the professional zoo technician and indirectly agricultural actors, we challenge transforming production systems towards more sustainable ones and innovating comprehensive disease prevention and control strategies and feeding strategies with pastures and feed. We propose that the opening of new production areas (such as the devastation of forests) can be replaced with technologies capable of maintaining the levels of productivity of the land, in the same quantity and quality, within a reduced area. In addition, there is immense genetic diversity and variability within domestic species of zoo technical interest, which could contribute to improving productivity, hardiness, resistance to pathogens, among others. On the other hand, there is evidence of the generation of Greenhouse Gases in enteric fermentation species, but these nutrient leaks can be treated using better quality forages and feed. In the case of grazing livestock, adequate stocking, care of the soil, rational use and treatment of water and the protection of flora and fauna of wild ecosystems, may contribute to the path of sustainable development (Gudynas, 2003). There are valuable experiences at the national level, where agricultural and livestock activities are given an ecosystem and intertemporal approach. For example, in Ica (Peru), emphasis is placed on natural capital and its contribution to the development of asparagus cultivation and the capacity of producers in soil conservation and efficient use of water, for this it still requires improvements in training, extension services and access to credit (Gómez and Flores, 2015). Another is the one we have in Matsés (Loreto - Peru), where permaculture has been implemented, defined as a sustainable agriculture technique that imitates the patterns and relationships that occur in nature to reduce the felling of trees to increase the cultivation of the field, allowing the production of abundant food, fiber, energy and medicine to meet local needs (McCarthy, 2018).

We also agree with some strategies indicated by FAO to promote environmentally sustainable livestock farming. For example, silvo pastoral and rotational grazing, controlled exclusion of livestock in fragile areas, conservation tillage, cover crops and agroforestry. In the same way, improvement of diets that reduce enteric fermentation and proper management of manure and biogas. In the same way, more efficient use of irrigation systems, design of zoning regulations and taxes that discourage the concentration of the large-scale livestock industry near cities, implementation of safeguarding wild areas, delimitation of protection strips, conservation easements or conservation tools, control of tax credits and criminal penalties and setting prices and rates that reflect environmental and economic costs, including all externalities.

\section{Final Thoughts}

Globalization is leading us to an archipelago of wealth but surrounded by a sea of environmental and social poverty. The search for sustainable development is an urgent need in today's world. In that sense, of all human activities, livestock activity plays a fundamental role for endogenous development in its economic, environmental and social dimensions. Given the negative balance between benefits and negative impacts, livestock activity requires restructuring or adjusting its foundations for exemplary professional and scientific practice. While political will is critical to tackling these difficulties, it is not enough. These strategies must go hand in hand with population growth control, healthy eating promotion, adaptation of sustainable farms through education from primary levels.

The SDGs are a valuable guide to understand the contribution of zoo technics, not only of animal production as an economic activity, but also to what its process implies within society and in an environmental setting. The conversion of zoo technics according to these SDGs will reaffirm its importance within society, positively impacting the security and food sovereignty of the peoples, contributing to the conservation of agrobiodiversity and natural resources. In this line, the strategic planning of decision makers is essential, promoting specific policies for each context, with a common objective.

The analysis of all perspectives allows us to make a necessary critique of what was done and what we are doing to promote change. Educational innovations are part of the solution, as long as the entrepreneurial spirit, creativity and equity are combined. It starts from small individual actions such as using fewer inputs, properly managing nutrients, reducing waste to the environment and rethinking our consumption habits to more global actions such as meeting Sustainable Development Goals.

\section{Funding Information}

This study was funded by fondecyt "Programa Doctoral en Ciencias para el Desarrollo Sustentable-FONDECYT2018-FONDECYT", through its executing unit ProCiencia [Contract No. 003-2018 FONDECYT/BM].

\section{Author's Contributions}

José Américo Saucedo Uriarte, ${ }^{1}$ Hurley Abel Quispe Ccasa: Conceived and designed the manuscript. wrote the first draft of the manuscript. 
Ilse Silvia Cayo Colca and Manuel Emilio Milla Pino: Analyzed and critically reviewed the manuscript. All authors read and approved the final manuscript.

\section{Ethics}

This manuscript is original and all reports were cited.

\section{References}

Arias, C. (2013). La actividad del Médico Veterinario en apoyo del desarrollo sustentable del pequeño agricultor.

Brundtland, G. (1987). Nuestro futuro común. Comisión Mundial sobre el Medio Ambiente y el Desarrollo. (Digitized by Dag Hammarskjöld Library). Asamblea general de las Naciones Unidas, pp, 416.

Buxade, C. (2000). Bases de producción animal. MundiPrensa. Madrid, España, pp, 342.

Dejo, F., Ventura, J. (2017). Perú: Indice de desarrollo sostenible. ESAN | Graduate School of Business, pp, 1-5.

Delgado-Callisaya, P. Á., Centellas, N., \& Villavicencio, W. (2014). Importancia y finalidad de la Zootecnia dentro de las Ciencias Agropecuarias. Journal of the Selva Andina Animal Science, 1(1), 21-23. http://www.scielo.org.bo/scielo.php?pid=S231125812014000100004\&script=sci_arttext

Fairfield, T. (2006). The politics of livestock sector policy and the rural poor in Peru (No. 855-2016-56206). Pro-Poor livestock policy initiative. FAO, https://core.ac.uk/download/pdf/7055429.pdf

Frolov, I. (1984). Diccionario de Filosofía, http://www.filosofia.org/urss/ddf1984.htm

Gallopín, G. C., Funtowicz, S., \& Ravetz, J. (2000). 1 Science for the 21st century: From social contract to the scientific core.

http://citeseerx.ist.psu.edu/viewdoc/summary?doi=1 0.1 .1 .511 .824

Gärtner, L. M. O. (2011). Zootecnia, por una adecuada productividad animal. Revista Universidad Católica de Oriente, 24(31).

Gómez, R., \& Flores, F. (2015). Agriculture and ecosystem services: A case study of asparagus in Ica, Peru. Apuntes, 42(77), 09.

González, B. K. M., \& Jiménez, R. A. J. (2012, February). Pequeña producción animal como alternativa de sustentabilidad: Perspectivas del estudiante en medicina veterinaria y zootecnia. In Congreso Universidad.

Gracia-Arnaiz, M. (2021). Eating issues in a time of crisis: Re-thinking the new food trends and challenges in Spain. Trends in Food Science \& Techology, In Press, Journal Pre-proof. doi.org/10.1016/j.tifs.2021.06.003

Gudynas, E. (2003). Ecología, economía y ética del desarrollo sostenible.

https://digitalrepository.unm.edu/cgi/viewcontent.cg $\mathrm{i}$ ? article $=1133 \&$ context $=$ abya_yala
Kates, R., Clark, W., Corell, R., Hall, J., Jaeger, C., Lowe, I., ... Faucheux, S. (2001). Sustainability science. Science, 292(5517), 641-642. doi.org/10.1002/9781118786352.wbieg0279

McCarthy, M. (2018). Sustainable agriculture in Peru for the Matsés people. Agriculture, Peru, Sustainability. The Borgen Proyect.

https://borgenproject.org/sustainable-agriculture-inperu/

Novo Villaverde, M. (2009). La educación ambiental, una genuina educación para el desarrollo sostenible. Revista de educación.

https://redined.educacion.gob.es/xmlui/handle/1116 2/74555

Novo Villaverde, M., \& Zaragoza, F. M. (2009). El desarrollo sostenible: Su dimensión ambiental y educativa. Universitas, Madrid Green, Duncan (2008) De la pobreza al poder: Como pueden cambiar el mundo ciudadanos activos, Barcelona, Fundación Intermon Oxfam.

Orihuela, C., and Rojas, R. (2017). Desarrollo sostenible en el Perú: Evidencia del periodo 1994-2015. Anales Científicos, 78(2), 130-138. doi.org/10.21704/ac.v78i2.1049

Romero, J. R., López, M. O., \& Salazar, J. C. (1994). El desarrollo sostenible una estrategia global con restricciones locales. Revista de la Facultad de Medicina Veterinaria y de Zootecnia, 42(1), 25-28. https://revistas.unal.edu.co/index.php/remevez/articl e/view/48063

Rosental, M. M., \& Iudin, P. F. (1965). Diccionario Filosófico, http://www.filosofia.org/urss/ddf1984.htm

Sepúlveda, S. (2003). El enfoque territorial del desarrollo rural. Iica. ISBN-10: 9789290395805.

Solano, D. (2007). Desarrollo, sostenibilidad y capacidades. Una trilogía indesligable. Journal of Economics, Finance and Administrative Science, 12(23), 9-27.

Steinfeld, H., Gerber, P., Wassenaar, T., Castel, V., Rosales, M., \& Haan, C. D. (2009). La larga sombra del ganado. Problemas ambientales y opciones (No. FAO-MED 15). Organización de las Naciones Unidas para la Agricultura y la Alimentación.

Vásquez, A. (2007). Desarrollo endógeno. Teorías y políticas de desarrollo territorial. Investigaciones regionales, $11,183-210$.

https://dialnet.unirioja.es/servlet/articulo?codigo $=25$ 00824

Vaughan, A. (2020). Global food crisis looms. New Scientist, 246, (3283), 7. doi.org/10.1016/S0262-4079(20)30946-5 
José Américo Saucedo-Uriarte et al. / Online Journal of Biological Sciences 2021, 21 (4): 322.328 DOI: 10.3844/ojbssp.2021.322.328

WBG. (2017). Gaining Momentum in Peruvian Agriculture: Opportunities to Increase Productivity and Enhance Competitiveness. Report produced under the Peru Agriculture Opportunities ASA.
Zalapa, A. (2012). La ganadería y el desarrollo sustentable. In VIII Congreso Internacional Sistema Agroforestales. Argentina: Editorial Inta Ediciones. 